\title{
Local nuances in the perception of nature protection and place attachment: a tale of two parks
}

\author{
Saska Petrova \\ Institute for Environmental Studies \\ Faculty of Science \\ Charles University in Prague \\ Benatská 2, 12801 Prague 2 \\ Czech Republic \\ petrova3@natur.cuni.cz \\ Stefan Bouzarovski \\ (corresponding author) \\ School of Geography, Earth, and Environmental Sciences \\ University of Birmingham \\ Tel: +44 (0)121 4142943 \\ Fax: +44 (0)1214145528 \\ buzars@adf.bham.ac.uk \\ Martin Čihař \\ Institute for Environmental Studies \\ Faculty of Science \\ Charles University in Prague \\ Benatská 2, 12801 Prague 2 \\ Czech Republic \\ mcihar@natur.cuni.cz
}




\title{
Local nuances in the perception of nature protection and place attachment: a tale of two parks
}

\begin{abstract}
The multiple social and political aspects of local residents' views towards the governance of national parks remain insufficiently investigated in the relevant theoretical and policy literature. Too often, such populations are seen as obstacles towards the sustainable management of national parks, as a result of their allegedly negative attitude towards nature conservation and protection. In order to challenge such views, we explore the attitudes and opinions of local residents towards nature protection and place attachment in two East and Central European (ECE) national parks: Pelister in the Republic of Macedonia and Šumava in the Czech Republic. Our analysis is based on expert interviews and a standardised questionnaire survey undertaken in both areas in 2009 and 2008, respectively. The research results identify some of the key differences in the local residents' perceptions of environmental governance and place in the two national parks, while emphasising the benefits of using a multi-method, geographically-aware approach towards the study of nature protection practices.
\end{abstract}

\section{Introduction}

The sustainable management of protected areas has become a major part of decision making processes in developed and developing countries alike, thanks to its farreaching spatial, cultural and economic implications (Antrop 2001). However, effective and durable nature protection cannot take place without the balancing of conservation objectives with the socio-economic aspirations of local communities (Ghimire and Pimbert 1997; Myers 2002; Brown 2003; Brockington et al. 2006; Hewett and Fletcher 2009). The active participation of local residents in the regulation of protected areas has increased the complexity of tasks faced by their management organisations, considering that the manner in which people perceive environmental quality and sustainability is influenced by, inter alia, socio-economic status, family ties and cultural affiliations (Wallner et al. 2007; Petrosillo et al. 2007). In part, this is because the socio-demographic structure of local communities may affect the acceptance of management strategies in a particular protected area, including the development of sustainable tourism and organic agriculture (for a further discussion, see, for example, Verbole 1995; Trakolis 2001).

A mounting body of research demonstrates that the individuals and local communities that have developed closer socio-economic and cultural bonds to an area display a higher degree of sensitivity to site management and impacts (Stokols and Shumaker 1981; Shumaker and Taylor 1983; Williams and Roggenbuck 1990; Williams et al. 1992; Vorkinn and Riese 2001). This may be due to the fact that place attachment, which can be defined as the 'affective link that people establish with specific settings, where they tend to remain and where they feel comfortable and safe' (Proshansky et al. 1983; Hidalgo and Hernández 2001; Hernandez et al. 2007) is closely associated with perceptions of home and belonging: 'people's senses of themselves are related to and produced through lived and imaginative experiences of home' (Blunt and Dowling 2006, 24). It thus follows that local understandings of the spatialities of the 
nature protection process and the character of protected areas themselves play a central role in the functioning of environmental management strategies.

Despite the fact that recent years have seen the publication of a wide range of academic and policy-orientated scholarship aimed at unravelling the multiple political and social aspects of local community participation in protected area governance (see, for example, Pimbert and Pretty 1995; Mehta and Kellert 1998; Kapoor 2001; Fraser et al. 2006), the role of national parks in this regard has received comparatively less attention. In particular, the manner in which different nature protection regimes have shaped the perceptions of national parks as management institutions, on the one hand, and inhabited places with a specific material and imagined geography, on the other, is insufficiently known. It remains unclear to what extent 'the crisscrossing of social relations, of broad historical shifts and the continually altering spatialities of the daily lives of individuals' (Massey 2001:462) has impacted the construction of attitudes towards nature protection policies in such areas. Much of the literature tends to conceptualise local residents and communities as either victims of, or obstacles towards, the sustainable management of national parks, as a result of their purportedly entrenched negative attitude towards nature conservation and protection. But there is insufficient empirical evidence to support the veracity of such claims across different regulatory and geographical settings (Lawrence 2008).

In light of such gaps in the literature, this paper explores the relationship between place attachment and perceptions of nature protection in two national parks in the Czech Republic and Macedonia (see Figure 1): two countries that have underwent major economic, social and political transformations of their environmental management regimes over the last 18 years (Young et al. 2007; Petrova et al. 2009), but have received insufficient attention in the relevant literature on the subject: a common situation across the Eastern and Central European (ECE) space to which they belong (but see, for example, Cellarius 2004; Staddon 2009). Using evidence drawn from in-depth interviews and standardised questionnaire surveys undertaken in Pelister National Park (Macedonia) and Šumava National Park (Czech Republic) between 2009 and 2008, the paper connects the attitudes of local residents towards the two national parks as geographical settings for the conduct of everyday life, on the one hand, with the history and politics or public participation and environmental management in the two areas, on the other. We are particularly interested in the extent to which, as argued by Vorkinn and Riese (2001) 'the values reflected through place attachment' also influence perceptions of management practices in national parks.

\section{(INSERT FIGURE 1 ABOUT HERE)}

Being aware of the complex and rich literature on place attachment and home - which has elaborated a wide array of inter-related concepts, including, inter alia, 'community attachment', 'sense of community', 'place dependency' and 'place identity' (Kasarda and Janowitz 1974; Sarason 1974; Stokols and Shumaker 1981; Shumaker and Taylor 1983; Proshansky 1983; de Sans 2004) - our broader purpose in the paper is to explore the extent to which attitudes towards place, space and the management of national parks vary among different groups of residents and areas, in order to ascertain the claim that local populations cannot be treated as uniform and monolithic with respect to nature protection. By using a spatially-contingent approach that emphasises the subtleties of social relations at the interface between local people 
and protected nature, we would like to demonstrate that a geographically-based approach can provide a powerful methodological arsenal to interrogate this claim.

\section{Case study areas and methods}

As noted above, the choice of our two case study countries was motivated by the broadly similar nature of the dramatic socio-economic changes that they have underwent during the past 18 years. These transformations created a unique set of circumstances in which the internal workings of space, society and nature become exposed and easily available to scholarly scrutiny (Tickle 2000; Bartoš et al. 2008; Kluvánková-Oravská et al. 2009). But Macedonia and the Czech Republic are at different stages of development and consequently face different socio-economic challenges: while the former is still a developing EU-accession state, the latter is a full EU member and has achieved levels of development that are almost on par with its Western European neighbours (Tickle 2000).

What makes Pelister and Šumava similar, however, is the fact that both parks are mountainous, forest areas, situated on the border with Greece in the case of former and Germany and Austria in the case of the latter. As such, the parks lie adjacent to similar protected areas in neighbouring countries. Both of them have been designated at the state level and are managed by hierarchically organised and rigidly-structured authorities, strictly controlled by the respective central governments. Pelister and Šmava alike are second category protected areas according to International Union for the Conservation of Nature's classification, and as such are meant to contain formally at least - similar zoning patterns and management practices.

Our field research involved a mixed-method approach (Winchester 1999; Kwan 2004) that included both qualitative and quantitative analyses, based on the use of in-depth 'stakeholder' interviews and a standardised questionnaire survey. We spoke to 20 (10 in each park) local residents, policy makers, advocacy activists and business sector representatives. The interviews, which lasted approximately one hour, were recorded and later transcribed. Having been analysed interpretively, they are not cited individually in the paper but form a significant part of the evidence base.

We also undertook a questionnaire survey of 131 and 182 households in Pelister and Šmava, respectively (the structure of the sample is described in Tables 1 and 2). It was executed during the summer of 2009 in the case of the former, and 2008 in the case of the latter. The survey questionnaires - which were identical to each other, except for three questions that referred to local conditions and problems - dealt with the socio-demographic characteristics of the respondents, their attitudes towards the national parks and their management, as well as issues of tourism and sustainable development. We targeted the questionnaires towards a sample of local villagers and second home owners from six (in the case of Šumava) and three (in Pelister) rural settlements situated in or around the parks (see Figures 2 and 3). In light of the numerous controversies surrounding the delineation of nativity and local residence (Mulder and Coppolillo 2005) we used the standard definition of the term 'resident' provided by the Oxford English dictionary: 'a person who lives somewhere permanently or on a long-term basis'. Thus, the survey sample also included second home owners and locally-born villagers whose official place of residence may have 
been elsewhere, but nevertheless possessed a home in the park and were present at the time of the survey.

\section{(INSERT TABLES 1 and 2 ABOUT HERE)}

As a result of the specific nature of Pelister National Park - its boundaries mainly skirt the edges of inhabited areas without encompassing them - two of the case study villages are located $1 \mathrm{~km}$ outside the borders of the park, although forest and agricultural land belonging to its residents lies within it. In the case of Šumava, which covers a much larger area (69,030 hectares), we selected six villages from the central part of the park. Since the chosen villages are relatively small, every single house was visited as part of the sampling procedure; the visit would not be repeated if there was no response at the door. Only one person per household would be interviewed usually the one who answered the door. The interviews lasted between 15 and 20 minutes, and would take place inside the respondents' homes (since many authors consider interviewing respondents in their domestic environment as a relative advantage in this regard, see Disman 1993). The response rate in Pelister was 97 per cent, mainly thanks to the fact that the surveys took place during summer village festivities when local customs stipulate that the door of the house must be open to any visitor. In Šumava, the response rate was 86 per cent.

Considering that one of the main aims of our research - as outlined in the introduction above - was to provide a more nuanced view of the local residents' understandings and experiences of nature protection in the two parks, we set out to explore the different ways in which the surveyed residents' perceptions of the multiple dimensions of national park governance related to their residential attachment to the area in which they live. We analyzed and cross-tabulated the evaluation of the statement 'Do you feel at home in the national park' (using a five-level Likert scale from 'strongly agree' to 'strongly disagree') against those relating to the two national park authorities' local service management, nature protection, and educational and cultural functions. Our decision to use the concept of 'home' as a proxy for place attachment was based on discussions in the relevant literature on the subject, where a number of authors working have argued that populations with a stronger connection to protected areas that are perceived as 'home' are more likely to be critical about, and interested in, local developments (see Kaltenborn 1998; Kaltenborn et al. 1999; Caruss et al. 2005; Manzo and Perkins 2006).

In the remainder of the text, we outline the key ways in which the local residents' attachment to the places in which they live relate to their appraisal of these three functions, set within the context of past nature protection challenges and broader socio-economic restructuring patterns in both areas.

\section{Pelister National Park: diverse local circumstances and perceptions}

Founded in 1948, Pelister is the first national park in the Republic of Macedonia and one of the oldest protected areas of its kind in the Balkans. Being located in the southwestern part of the country, the park is very close to the border with Greece. It is also less than 15 kilometres away from Bitola, Macedonia's second largest city. Pelister occupies the north parts of the Baba mountain massif, between altitudes of 891 and 2601 metres above sea level (see Figure 2). The park presently covers a total area of 
14,300 hectares, thanks to the expansion of its boundaries in 2007 (Petrova et al. 2009). Its key attributes include extensive forests of Macedonian pine (Pinus peuce), which occupy a relatively large area of the park's northern slopes, and are among the Balkans' best-developed and most extensive ecosystems formed by this very rare and endemic pine (Nastov and Micevski 1994; Nastov 2000). The Macedonian pine forms two different types of vegetation communities on the territory of the park, including mountainous woodland (Digitali viridiflorae - Pinetum peuces) at altitudes ranging from 900 and 1600 metres above sea level, and sub-alpine woodland (Gentiano luteae - Pinetum peuces), which is usually present between 1500 and 2100 or more metres above sea level.

\section{(INSERT FIGURE 2 ABOUT HERE)}

The Pelister National Park Authority is the main site-based state institution entrusted with the management of the park. It is entirely controlled by the central government, with a manager appointed directly by the Minister for Environment. The authority was - and to a large extent still is - organised along the lines of a forest enterprise, as its activities have historically been concentrated on forest management and timber trade. There has been a movement away from the exclusive focus on such operations during the past decade, however, mainly thanks to the formulation of a comprehensive management plan - the only such document in Macedonia to date. The country's inflexible legislative framework and its rigid legal management structure for nature protection have forced the national park authority to develop and implement several alternative modes for effective local participation in the management and protection of the park (Petrova et al. 2009), even though the lack of personnel and finances have presented a continuous challenge towards the development of an effective nature protection framework.

As noted above, Pelister's territory includes only one rural settlement - the village of Malovishta - within its boundaries. However, a number of villages that are well known for their cultural and architectural heritage line the boundaries of the park. They include, inter alia, Nizhepole, Brajchino, Kazhani, Rotino, Capari, Magarevo, Trnovo and Dihovo. Although the Pelister region traditionally had an extensive agricultural economy - mainly based on sheep husbandry - many families from the region emigrated to Canada, USA, Australia, and the Scandinavian countries by the middle of the twentieth century, leaving the area sparsely populated. During socialism, the economy of all rural settlements in the region hinged on the development of food-processing, textile and manufacturing industries in the nearby cities of Bitola and Resen, although agricultural activities continued to be present as well.

Following the collapse of the socialist system in the 1990s, nearly all industrial plants in the two cities were closed or privatised, which forced local people to turn towards alternative economic practices. As a result, nature-based tourism and the trade in nontimber products (different types of berries) slowly started to expand in the Pelister region. They started to influence migration trends as more and more people started to moved to the area in order to exploit these opportunities. For example, 30 new holiday homes - many of which are intended for B\&B accommodation - were constructed in Nizhepole between 2007 and 2009. As pointed out by one of our interviewees: 
'I bought some land here and built a house in order to start a new business in the tourism sector. Thanks to its favourable location and easy accessibility, Nizhepole is perfect for this' (personal communication, 09.08.2009)

Our interviews with some of the oldest residents from the same village, however, indicated that their attitudes towards this question were not always positive:

'A significant number of new people are coming into the village ... they are buying agricultural land and building large new houses without any building permission. These houses are outside the planning framework, there are no water and waste facilities for them ... some of their owners throw rubbish into the river' (personal communication, 09.08.2009).

Still, some locals saw ostensible benefits from the expansion of second and holiday home ownership:

'Thanks to the increased number of people in the village we finally have a shop and we do not have to go to the city to buy everyday essentials, including food' (personal communication, 10.08.2009).

Many of the people we spoke to expressed a strong attachment and sense of belonging in relation to the village and national park per se:

'We wouldn't like to move anywhere else ... we live to next to such incredible and clean nature. I am not pleased with how the national park authority and local council function in the area, but the national park is here, and it is my home regardless of who is running it' (personal communication, 10.08.2009).

While most of the tourist accommodation in Nizhepole has been constructed by recent in-migrants, we encountered a different situation in Brajchino, where many local residents demonstrated an active interest in community and nature based tourism. They had thus established a local NGO in order to create fair and equal tourism opportunities for everyone in the village, in part by standardising prices for accommodation, home-cooked meals and tourist guidance. As one of our interviewees put it:

'The whole idea started thanks to the "Pelister Mountain Protection Project" realised by the Swiss NGO Pro-Natura in co-operation with two Macedonian NGOs. What really makes me happy is that our NGO still exists and functions although the project finished two years ago' (personal communication, 14.08.2009).

Aside from tourism purposes, Brajchino's residents also used the NGO for improving their communication with the national park authority, and getting involved in its management. They became direct participants in the decision-making process regarding the expansion of the park into the hinterland of the villages, and the setting of new boundaries in the area. The close relationship between local public participation and place attachment and dependency in this context was evident in many of the interviews: 
'We are glad that the national park involved us in its policy process regarding the expansion of its border. After all, the national park is literally in our backyard and our lives and destinies are strongly connected to what happens there' (personal communication, 14.08.2009).

We encountered a significantly different situation in Malovishta. Although this village is located in a picturesque location with a high concentration of natural and architectural heritage, it had the least developed tourism infrastructure compared to our other two study sites. The residents of Malovishta have been directly reliant on the park's natural resources and its management for their livelihoods, as the largest share of their income stems from employment in park services or the trade in nontimber products. Basically, in order to compensate for the limited use of timber resources, the authority has allowed local residents to be commercially involved in, and financially benefit from, from the trade of non-timber forest products, including Pinus peuce seeds, cones and blackberries. The provision of a wide range of local services - waste management, free fuelwood for heating, as well as the improvement and maintenance of local infrastructure, especially water - has also helped the park strengthen its relationship with the residents of the vilage (Petrova et al., 2009). Through this process, the national park authority's determination to develop flexible governance solutions that would allow local communities to benefit from the park's existence has helped overcome any potential conflicts over the management of the area.

Considering that the existence of the three settlements is highly dependent on the state of the environment and natural resource management in the park, it follows that their general model of development and patterns of everyday life are profoundly affected by the policy decisions made by the park management authority (European Agency for Reconstruction 2003). Yet the analysis of survey questionnaires indicated that that most local residents were largely apathetic towards, or unaware of, the role of the national park in providing local service management, cultural and educational functions, and nature protection (see Figure 4). This is despite the fact that an overwhelming majority of them saw the park as their 'home' (see Figure 5). It also transpired that the local residents' place attachment to the park was weakly correlated with the their level of (dis)satisfaction with the three surveyed aspects of the national authority's work (see Table 3). But there was a very strong correlation among the local residents perceptions of the park as an organisation responsible for providing local service management, nature protection, and culture and education, which suggests that they did not distinguish among the different roles of the national park authority.

\section{(INSERT FIGURES 4 AND 5 AND TABLE 3 ABOUT HERE)}

The lack of a strict delineation and regulation of movement paths in the park - which means that local residents and tourists are free to roam throughout the area - could have contributed to the lack of separate understandings of the park as 'home', on the one hand, vs. a nature protection regime managed by a specific institution, on the other. This situation might have also emerged as a result of the fact that tourism is still poorly developed in the region, which means that pressure on environmental quality and living costs is insignificant. Also, the intensity of residential development in the area was still much lower than the limits prescribed by national-level nature 
protection legislation. In this context, it is worth noting that Pelister has historically never seen a strong clash of opposing interests with respect to the utilisation and management of natural resources.

\section{Šumava National Park: nature protection and place attachment remain strongly connected}

Having been founded in 1991, Šumava is the largest national park in the Czech Republic with a total area of 69030 hectares. The park encompasses a significant section of the wider Sumava mountain region and is situated along the southwest border with Germany and Austria, at altitudes between 600 to 1378 metres above sea level (see Figure 3). At the outskirts of the park one finds the Šumava protected landscape area, which partly serves as an outer buffer zone. In 1990, the total area of Šumava protected landscape area and national park was designated as UNESCO Biosphere Reserve, thus forming a continuous whole with the Bayerischer Wald Biosphere Reserve in Germany. Together, the two reserves create the most extensive intact forest in Central Europe. Thanks to its natural features, the region has received wider international recognition, becoming a part of the European network Natura 2000 in 2004. The Šumava peat bogs have been declared a Ramsar site, while the area's geomorphological features - primarily glacial relics - are listed in the IUCN Red Book of ecosystems (Cihar et al. 2000).

\section{(INSERT FIGURE 3 ABOUT HERE)}

A single authority is in charge of managing both the national park and protected landscape area. It possesses a multilayered top-down structure with a director appointed by the central Government. In 2006, following the broader efforts of the Czech Republic to adapt its legal acts in line with relevant EU standards (Cihar et al. 2000; Cihar and Stankova 2006; Furlong 2006; Kušová et al. 2002; 2005; 2008) the authority underwent a major process of organisational reform, which resulted in the establishment of six departments in place of the previous ten forest administrations. The restructuring was aimed at transforming the authority from a forest enterprise into an organisation that will take responsibility not only for forest management but will also spawn the integrated nature conservation and sustainable local development of the park. The authority was also equipped with public relations and marketing departments in order to improve its communication and co-operation with local stakeholders0. Despite these changes, however, the management of the park is still mired in conflicts with its resident population.

The wider region that hosts the national park is one of the most sparsely settled in the Czech Republic, with a population density of only 1.3 inhabitants per square kilometre. A total of 22 settlements are partially or fully located within or around the boundaries of park, although six villages - Borová Lada, Kvilda, Horská Kvilda, Srní, Prašily and Modrava - lie in the immediate proximity of its main tourist attractions, thus attracting the greatest number of visitors. The low population density of the area is mainly a result of the dramatic economic and social changes that it witnessed throughout the twentieth century. These transformations were associated with the gradual displacement and selective re-colonisation of local populations, thanks to which the area shifted from an agricultural and forestry-based economy in the first half of the twentieth century, into a remote, resourced-based region with a military 
training area in its second half (Tickle 2000). The establishment of the Iron Curtain made the region almost inaccessible for 50 years.

The last two decades have been associated with a dramatic turnaround of the economic and social profile of the region, as a result of the post-communist transition. Furthermore, the management practices of the park have changed from a highly interventionist approach - involving the cutting and removal of vulnerable tree stands - towards a 'natural', non-interventionist strategy aimed at fostering the selfregeneration of the forest. Both phases have excluded the local residents in different ways: in the first instance, forest exploitation was subcontracted to external companies and took place in areas that were outside the reach of the park's inhabitants, while the later phase, inter alia, has led to the reduction of employment opportunities for local residents as full or part-time woodcutters. At the same time, local residents still cannot access all parts of the park, as paths of movement through the area are strictly defined, and the right of entry into the first zone of 'strict protection' remains prohibited. As pointed out by one of our interviewees:

'We wouldn't mind it so much if the first zone was off-limits to everyone, but it is not fair if local people can't even walk there while people from the authority are allowed to drive guests in huge jeeps through them. Of course we hear the same excuse all the time, that all of their visits to the first zone are for scientific purposes' (personal communication, 07.08.2008).

Moreover, thanks to the ample possibilities for nature-aware tourism afforded by its attractive natural and historical heritage, Šumava is currently faced with new demographic and economic challenges. These include amenity migration and intense tourism development, which according to some of our interviewees, have been considerably affected by the policy of the park's authorities:

'When me and my husband wanted to reconstruct our family house it was really hard to get building permission, but at you see now they are building a whole residential complex for rich foreigners in our small village' (personal communication, 09.08.2008).

It should be pointed out, however, that the authority has managed to implement a number of measures that are seen favourably by the local residents and favour the common interests of all users of the park, mainly with respect to the management of tourist flows. These include the maintenance of cross-country ski tracks, the establishment of 'ecological' buses, the construction of information centres and the rehabilitation of public landmarks in the park (Kušová et al. 2008). It is also expected that the state of waste and wastewater treatment facilities will be improved at the beginning of 2010, thanks to the initiation of a new government programme for regional project finance in this sector. Still, some residents thought that the park authority is more interested in pleasing tourists rather than locals:

'They are doing things only for the tourists. We, the older, retired people are just left on our own. There is not even a pharmacy close enough, so I have to buy my medicines in the city, but for the tourists there are information centres in every village' (personal communication, 13.08.2008) 
It also transpired that the local residents who do not have enough capital to invest into tourist services find it really difficult to start a new business, even though Bartoš et al. (2008) argue that amenity migrants using information technology represent a new class in the Czech Republic and especially in the Šumava region. As pointed out by a local shop owner:

'Unfortunately small business like mine are not eligible for most of the available funds' (personal communication, 11.08.2008)

Our quantitative investigation of the local residents' views of Šumava as their home, on the one hand, and a national park authority with three different functions, on the other, indicated that this area was in slightly different situation compared to Pelister, since the residents' views of these two aspects of the park's role were highly correlated (see Table 4). While the structure of answers to the questions about the three different roles of the park was mixed (ranging from 'very satisfied' to 'very dissatisfied' in almost equal proportions: see Figure 4), the evaluation of place attachment to the park was significantly weaker compared to Pelister (see Figure 5). This is despite the fact that approximately $90 \%$ of respondents still broadly identified with the park as 'home'. To summarise: although we uncovered a strong correlation between the local residents senses of 'home' and views of the three functions of the park, on closer inspection we discovered a disjuncture between their overall positive appraisal of the former, vs. mixed feelings towards the latter.

\section{(INSERT TABLE 4 ABOUT HERE)}

Just like in Pelister, however, the respondents failed to distinguish among their perceptions of the park as an organisation responsible for providing local management services, nature protection and cultural and educational work, as evidenced by the strong correlations between their answers to these questions. In general, it appears that the intense pace of tourism growth and economic development in the park has resulted in traffic problems and other forms of disturbance that are visibly perceived by the locals. This hasn't prevented them, however, from retaining a generally positive attitude towards the residential significance of the park for the conduct of their everyday lives. In addition to the continued threat of increased tourism, their mixed - but overall rather uniform - appraisal of the different roles of the national park may stem from the rigidity and restrictiveness of its nature protection regime, which limits freedom of movement and employment opportunities.

\section{Conclusion}

This evidence reviewed in this paper points to the existence of a number of underlying differences in the relationships between the nature protection and place attachment in Pelister and Sumava. The specific historical trajectories of the host regions of the two parks have combined with the idiosyncracies of their political, social, economic and institutional circumstances to produce a divergent and variegated array of interactions between local residents and the regulatory practices of environmental management organisations.

The Pelister National Park Authority has managed to develop a relatively successful co-operation dynamic with the local residents, which chimes in well with their strong 
sense of belonging and attachment to the area. This situation has transpired despite the residents' lack of information about, and insufficient involvement in, the decision making and management of the park. Although Pelister's residents are strongly attached to the park as their home, they are largely unfamiliar with, or uninterested in, the authority's overall work. The nature protection and environmental governance issues in Šmava, where local residents are significantly more dissatisfied with the work of the national park authority, are markedly different. The human population of the park has maintained a close attachment to the area despite a range of local conflicts with the management structures of the park, and a mixed appraisal of its operation.

In its entirety, our research has demonstrated that local residents have a strong sense of place attachment in relation to the national parks in which they live. But local populations cannot be treated as a monolith in terms of their views of national park management, which are not necessarily correlated to perceptions of place attachment. Future research endeavours in this field could take upon the task of further exploring socio-spatial differences in the perception of home, belonging and place within protected areas, while establishing the role of different participation models in creating such differences. With its ability to provide a comprehensive conceptual and epistemological framework involving sophisticated theorisations of place, nature and human behaviour, we would argue, geography is in an ideal position to play a central role in this undertaking.

\section{Acknowledgments:}

The authors wish to thank the interviewees from both parks for their kind cooperation and assistance, and Dimitrije Buzarovski for his assistance in undertaking the statistical analyses. Saska Petrova and Martin Čihař also wish to thank the ESF (project no. CZ.04.3.07/3.1.01.3/3348) and the Ministry of the Environment of the Czech Republic for the financial support provided towards the execution of fieldwork data gathering (project VaV-SP/4i2/40/08). Part of Stefan Bouzarovski's work on this paper was supported by the Ministry of Education, Youth and Sports of the Czech Republic, project no. MSM0021620831: " Geographic Systems and Processes in the Context of Global Change and European Integration'. 


\section{References:}

Antrop M 2001 The language of landscape ecologists and planners: a comparative content analysis of concepts used in landscape ecology Landscape and Urban Planning 55 163-173

Bartoš M, Kušová D, Těšitel J, Kopp J and Novotná M 2008 Amenity migration in the context of landscape ecology research Journal of Landscape Ecology 15 21

Blunt A and Dowling R 2006 Home Routledge, London

Brockington D, Igoe J and West $\mathbf{P} 2006$ Parks and peoples: the social impact of protected areas Annual Review of Anthropology 35 251-277

Brown K 2003 Trees, forests and communities: some historiographical approaches to environmental history on Africa Area 35 343-356

Cellarius BA 2004 In the Land of Orpheus: Rural Livelihoods and Nature Conservation in Postsocialist Bulgaria University of Wisconsin Press, Madison

Cihar M and Stankova J 2006 Attitudes of strakeholders towards the Podyji/Thaya River Basin National Park in the Czech Republic Journal of Environmental Management 81 273-285

Cihar M, Tancosova $\mathbf{Z}$ and Trebicky V 2000 Selected aspects of the sustainable development in Sumava National Park as seen by the local residents Silva Gabreta 5 195-216

de Sans ÀP 2004 Sense of place and migration histories Idiotopy and idiotope Area $36348-357$

Disman M 1993 Jak se vyrábí sociologická znalost Vydavatelství Karolinum Univerzita Karlova, Praha

European Agency for Reconstruction 2003 Pelister Tourism Development Study: Development Concept Report European Agency for Reconstruction, Thessaloniki

Fraser EDG, Dougill AJ, Mabee WE, Reed M and McAlpine P 2006 Bottom up and top down: analysis of participatory processes for sustainability indicator identification as a pathway to community empowerment and sustainable environmental management Journal of Environmental Management 78 114127

Furlong K 2006 Unexpected narratives in conservation: discourses of identity and place in Šumava National Park, Czech Republic Space and Policy 10 47-65 
Ghimire KB and Pimbert MP 1997 Social Change and Conservation Earthscan, London

Hernández B, Hidalgo MC, Salazar-Laplacea ME and Hessc S 2007 Place attachment and place identity in natives and non-natives Journal of Environmental Psychology 27 310-319

Hewett T and Fletcher S 2009 The emergence of service-based integrated coastal management in the UK Area available online

Hidalgo MC and Hernández B 2001 Place attachment: Conceptual and empirical questions Journal of Environmental Psychology 21 273-281

Kaltenborn BP 1998 Effects of sense of place on responses to environmental impacts: A study among residents in Svalbard in the Norwegian high Arctic Applied Geography 18 169-189

Kaltenborn BP, Riese H and Hundeide M 1999 National park planning and local participation: some reflections from a mountain region in Southern Norway Research and Development 19 51-61

Kapoor I 2001 Towards participatory environmental management? Journal of Environmental Management 63 269-279

Kasarda JD and Janowitz M 1974 Community attachment in mass society American Sociological Review 39 328-339

Kasarda JD and Janowitz M 1974 Community attachment in mass society American Sociological Review 39 328-339

Kluvánková-Oravská T, Chobotova V, Banaszak I, Slavikova L and Trifunovova S 2009 From government to governance for biodiversity: the perspective of Central and Eastern European transition countries Environmental Policy and Governance 19 186-196

Kušová D, Bartoš M and Těšitel J 2002 Role of traditions in tourism development in the Czech part of the Bohemian Forest Silva Gabreta 8 265-274

Kušová D, Bartoš $\mathbf{M}$ and Těšitel $\mathbf{J} 2005$ The media image of the relationship between nature protection and socio-economic development in selected protected landscape areas Silva Gabreta 11 123-133

Kušová D, Těšitel J, Matějka K and Bartoš M 2008 Biosphere reserves - An attempt to form sustainable landscapes. A case study of three biosphere reserves in the Czech Republic Landscape and Urban Planning 84 38-51.

Kwan M-P 2004 Beyond difference: from canonical geography to hybrid geographies Annals of the Association of American Geographers 94 756-763 
Lawrence A 2008 Experiences with participatory conservation in post-socialist Europe The International Journal of Biodiversity Science and Management 4 179-186(178)

Manzo LC and Perkins DD 2006 Finding common ground: the importance of place attachment to community participation and planning Journal of Planning Literature $20335-350$

Massey D 2001 Living in Wythenshawe in Borden I, Kerr J, Rendell J and Pivaro A eds The Unknown City: Contesting Architecture and Social Space MIT Press, Cambridge 459-475

Mehta JN and Kellert SR 1998 Local attitudes toward community-based conservation policy and programmes in Nepal: a case study in the MakaluBarun Conservation Area Environmental Conservation 25 320-333

Mulder BM and Coppolillo P 2005 Conservation: Linking Ecology, Economics, and Culture Princeton University Press, Princeton

Myers GA 2002 Local communities and the new environmental planning: a case study from Zanzibar Area 34 149-159

Nastov A 2000 Report of Nature Conservation in The Former Republic of Macedonia, Convention on the Conservation of European Wildlife and Natural Habitats Council of Europe, Strasbourg

Nastov A and Micevski B 1994 National Report of Status of Conservation of Biological Diversity in Protected Areas of the Republic of Macedonia UNEP, Geneva and Skopje

Petrosillo I, Zurlini G, Corlianò ME, Zaccarelli N and Dadamo M 2007 Tourist perception of recreational environment and management in a marine protected area Landscape and Urban Planning 79 29-37

Petrova S, Bouzarovski S and Čihař M 2009 From inflexible national legislation to flexible local governance: management practices in the Pelister National Park, Republic of Macedonia GeoJournal 74 589-598

Pimbert MP and Pretty JN 1995 Parks, People and Professionals: Putting 'Participation' into Protected Area Management. Discussion Paper No 57 United Nations Research Institute for Sustainable Development, Geneva

Proshansky HM, Fabian AK and Kaminoff R 1983 Place-identity: Physical world socialization of the self Journal of Environmental Psychology 3 57-83

Sarason S 1974 The Psychological Sense of Community: Prospects for a Community Psychology Jossey-Bass, San Francisco

Shumaker SA and Taylor R 1983 Toward a classification of people-place relationships: A model of attachment to place in Feimer NR and Geller ES 
eds Environmental Psychology: Directions and Perspectives Praeger, New York 219-251

Staddon C 2009 Towards a critical political ecology of human-forest interactions: collecting herbs and mushrooms in a Bulgarian locality Transactions of the Institute of British Geographers 34

Stokols D and Shumaker SA 1981 People in places: A transactional view of settings in Harvey D ed Cognition, Social Behavior, and the Environment Erlbaum, Hillsdale 441-488

Tickle A 2000 Regulating environmental space in socialist and post-socialist systems: nature and landscape conservation in the Czech Republic Journal of Contemporary European Studies 8 57-78

Trakolis D 2001 Local residents's perceptions of planning and management issues in Prespes Lakes National Park, Greece Journal of Environmental Management $61227-241$

Verbole A 1995 Tourism development in the European countryside: costs and benefits in Barbi A and Wastl-Walter D eds Sustainable Development of Rural Areas: From Global Problems to Local Solutions Klagenfurter Geographische Zeitung 13, Klagenfurt 60-75

Vorkinn M and Riese H 2001 Environmental concern in a local context: The significance of place attachment Environment and Behavior 33 249-263

Wallner A, Bauer N and Hunziker M 2007 Perceptions and evaluations of biosphere reserves by local residents in Switzerland and Ukraine Landscape and Urban Planning 83 104-114

Williams DR, Patterson ME and Roggenbuck JW 1992 Beyond the commodity metaphor: Examining emotional and symbolic attachment to place Leisure Sciences 14 29-46

Williams DR and Roggenbuck JW 1990 A framework for examining the meaning of recreation places: place attachment, mode of experience, and environmental dispositions in Gramann JH ed Proceedings: The Third Symposium on Social Science in Resource Management Texas A\&M University, College Station 7072

Winchester HPM 1999 Interviews and questionnaires as mixed methods in population geography: the case of lone fathers in Newcastle, Australia The Professional Geographer 51 60-67

Young J, Caspian R, Fischer A, Halada L, Kull T, Kuzniar A, Tartes U, Uzunov Y and Watt A 2007 Conflicts between Biodiversity Conservation and Human Activities in the Central and Eastern European Countries Ambio 36 545-550 


\section{Figure captions:}

Figure 1: Locations of the host countries and parks within the post-communist countries of Central and Eastern Europe (marked in grey).

Figure 2: Boundaries and key settlements of Pelister National Park (villages where the research was conducted are marked with black dots)

Figure 3: Boundaries and key settlements of Šumava National Park (villages where the research was conducted are marked with black dots)

Figure 4: Responses to the statement 'I am satisfied with the role of the national park authority' in three different respects, for Pelister and Šumava (based on authors' own survey)

Figure 5: Responses to the statement 'I feel at home in the national park' (based on authors' own survey) 
FIGURE 1

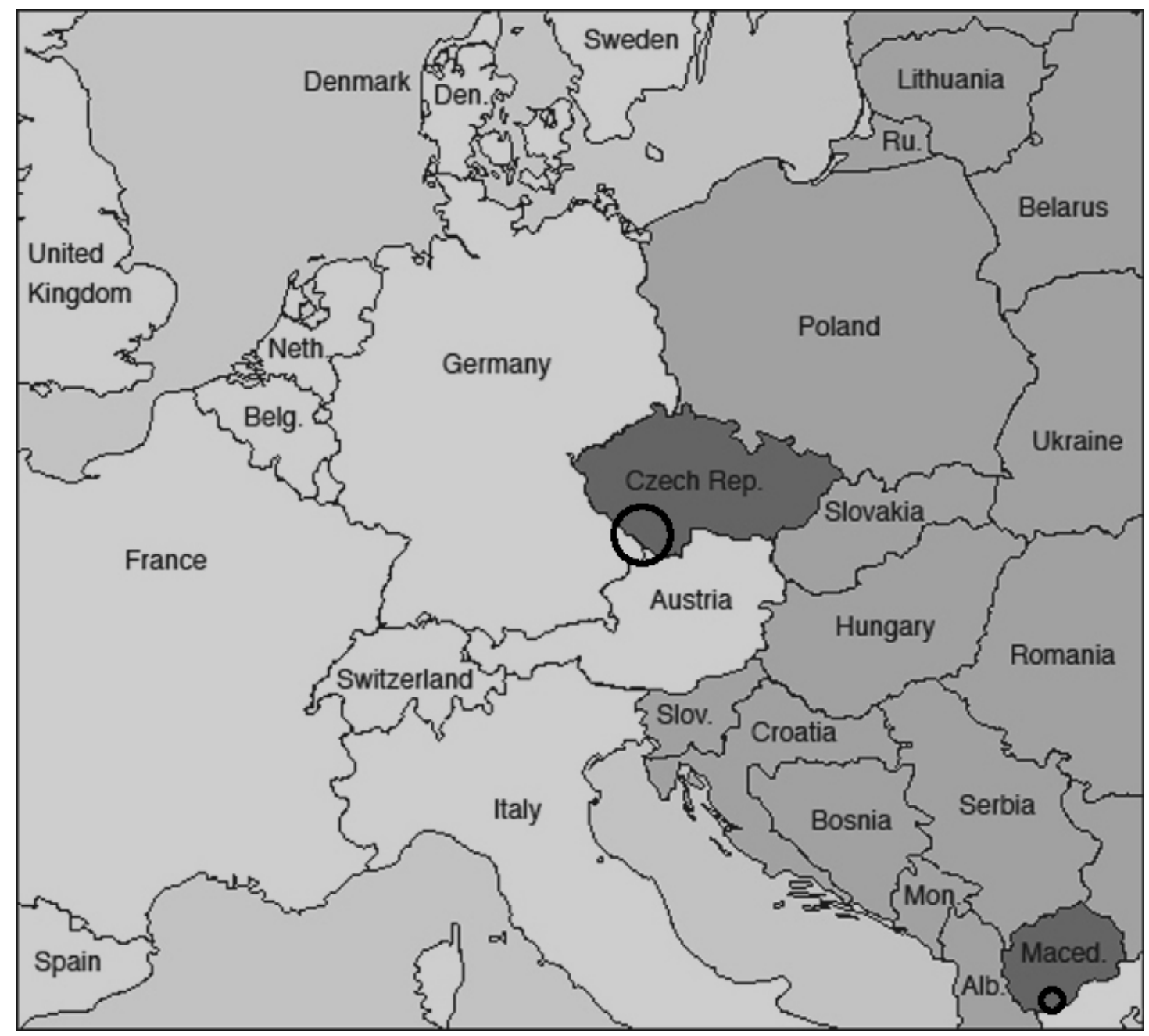




\section{FIGURE 2}

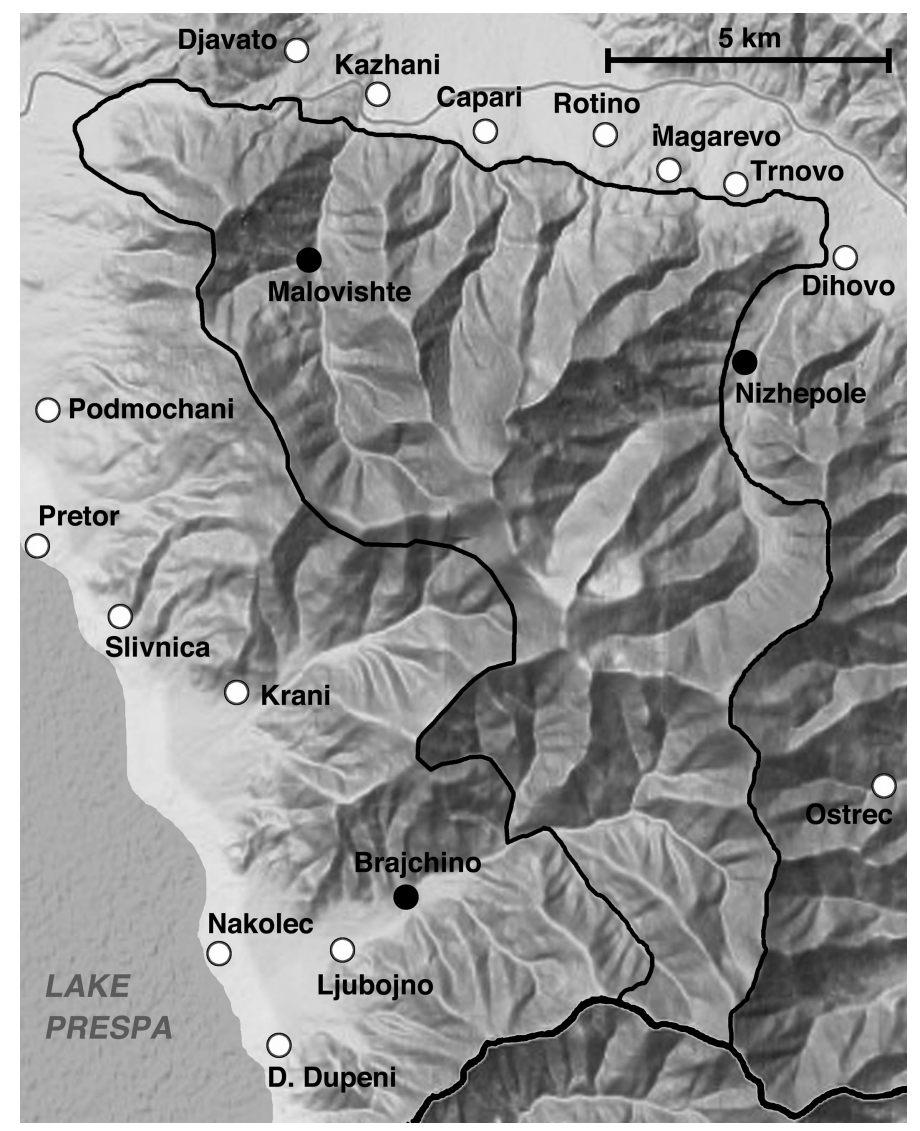




\section{FIGURE 3}

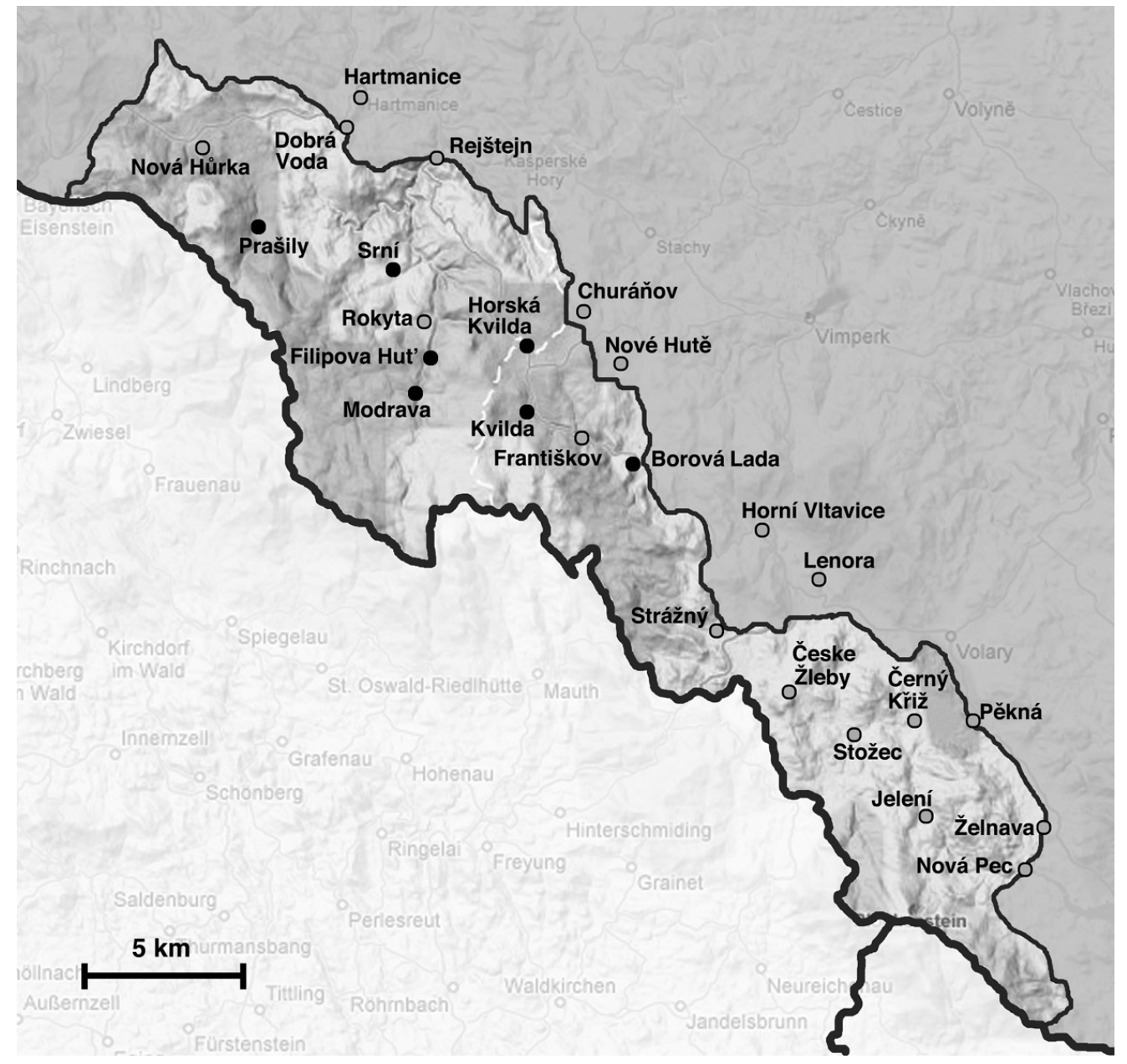


FIGURE 4

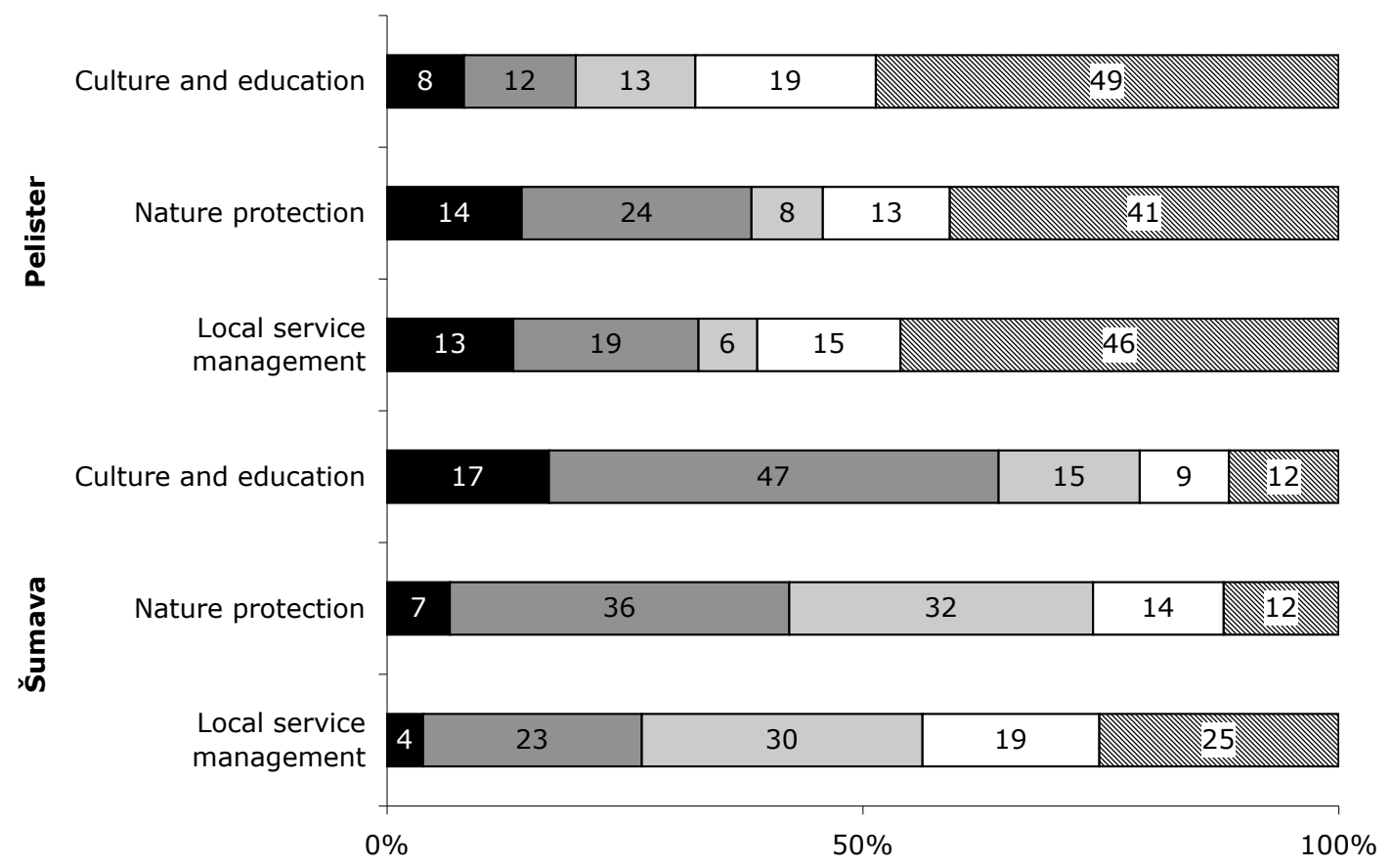

घery satisfied $\square$ Partly satisfied $\square$ Partly dissatisfied $\square$ Very dissatisfied $\quad$ Don't know 


\section{FIGURE 5}

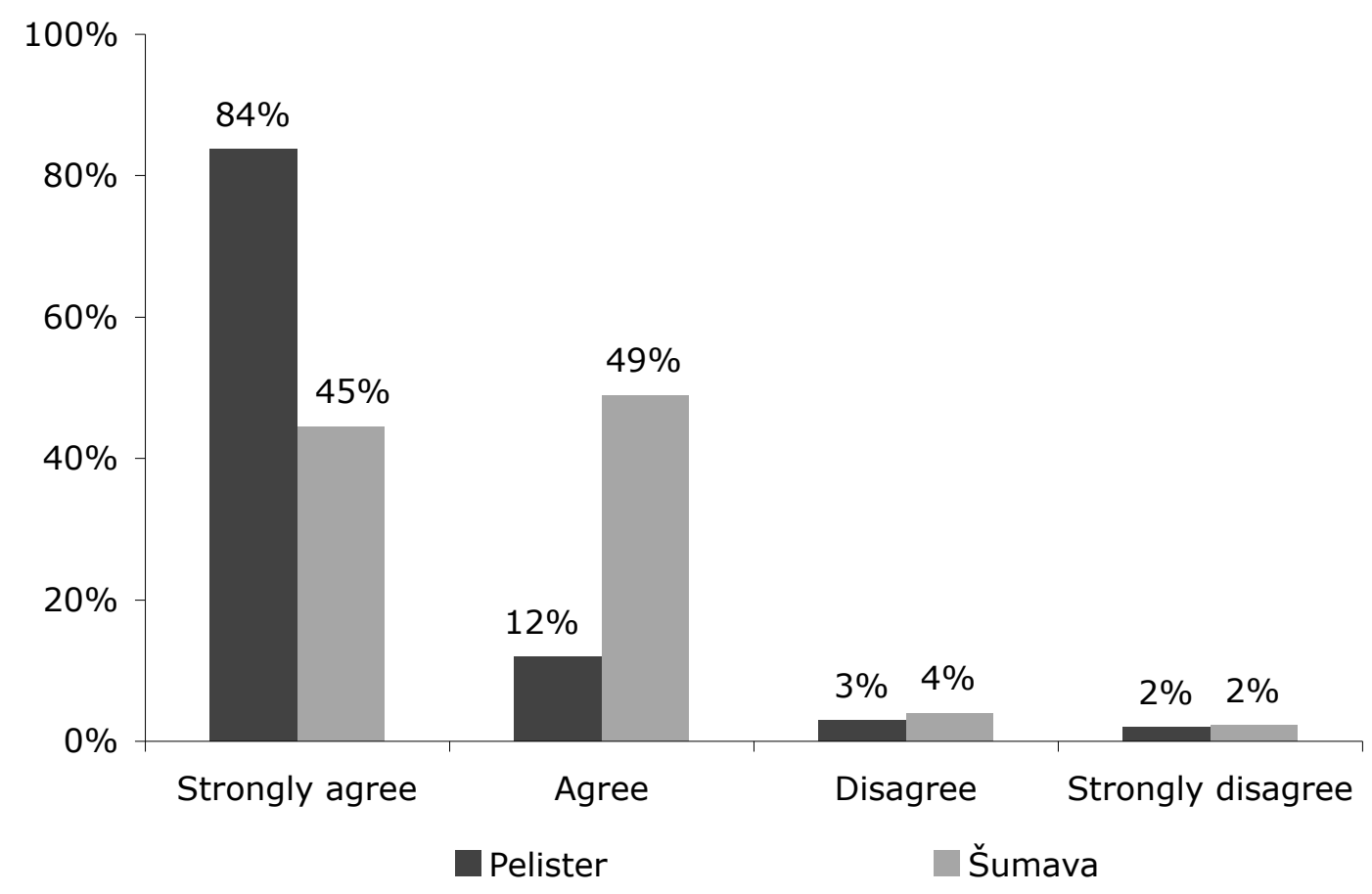

